\title{
Fairness and Equality in Insurance Classification*
}

\author{
Yves Thiery and Caroline Van Schoubroeck \\ K.U. Leuven University, Tiensestraat 41, Leuven B-3000, Belgium. \\ E-mail: yves.thiery@law.kuleuven.be
}

Insurance is to a large extent based on risk selection and classification. Legislators however are inclined to impose restrictions to these differentiations by banning those that are considered to be "discriminatory". Risk selection and risk classification are not disallowed by law, but each such decision requires a well-funded, that is, fair justification. The conditions for reaching a fair insurance-differentiation scheme could be clarified by bridging the apparent conflict between an "individualistic" human rights approach and an insurance "group" approach to equality. Therefore, a number of considerations concerning the notion of subsidy-aversion should be taken into account in the legal justification of unequal treatment. These considerations concern the notion of controllability of risks, the (im)possibility of establishing a causal relation between risk variables and the risk itself, scepticism of adverse selection in case where price-inelastic markets are concerned and the influence of tracing costs on the choice of risk variables.

The Geneva Papers (2006) 31, 190-211. doi:10.1057/palgrave.gpp.2510078

Keywords: discrimination; subsidy aversion; solidarity; adverse selection; tracing costs; risk controllability

\section{Introduction}

On 13 December 2004 the Council of the European Union adopted a Directive implementing the principle of equal treatment between men and women in the access to and supply of goods and services, including insurance (hereinafter cited as "European Directive Sex Discrimination Goods and Services"). "Drafts of this Directive have been widely debated in the media in various EU Member States. The Directive's impact on the European insurance market can hardly be underestimated. Indeed, the Directive prohibits taking a person's gender into account as a factor in calculating premiums or benefits (for the purposes of insurance and related financial services) in a manner that would result in differences in an individual's premiums and benefits.

This Directive is the most recent illustration of a growing tendency to enact general prohibitive discrimination legislation, not only at the European Union level ${ }^{2}$ but at the state level as well. The application of this legislation to insurance activities imposes legal restrictions on insurance differentiation by banning differentiation methods that

\footnotetext{
* The research of this paper was funded by the project "Risk selection and risk classification in private insurance practice: an inquiry into the legal boundaries of information - gathering by the insurer" (supervisor Prof. Herman Cousy) of the Belgian Fund for Scientific Research - Flanders.

${ }^{1}$ Council Directive 2004/113/EC.

${ }^{2}$ For an extensive overview see Waddinton and Bell (2001).
} 
are considered to be "discriminatory". These initiatives (which put into effect the principle of equal treatment between, for example, women and men, older and younger persons) are a response to the observation that applicants for insurance that do not represent an attractive risk are refused (affordable) insurance coverage or, when passing selection, are classified on the basis of factors that are either immutable such as gender or age, or that are mutable, such as smoking behaviour. Insurance is indeed based largely on risk selection and classification. However, many legislators are greatly concerned that this differentiation process deprives applicants for insurance of adequate insurance coverage in indispensable insurance services such as motor-vehicle insurance, life insurance or private health insurance.

The aim of these regulations is to ban discrimination in "horizontal" relationships. The regulations undoubtedly have a direct impact on individual and collective contracts, and on agreements concluded between private parties. They thereby clearly affect the contractual freedom and the freedom of enterprise, both well-established rights in national laws.

From an actuarial and economic point of view, it is important to point out that many of the regulations that prohibit discriminatory practices in the access to and supply of insurance services still allow the insurer to justify their classification system and the unequal treatment resulting from it as fair. In this paper, it is argued that the reason why insurers still vehemently oppose these regulations is that lawyers and legislators on the one hand, and insurers on the other, have profoundly different views on the concept of fairness in insurance classification. These different views on fairness boil down to a different approach to equality: an "individualistic" human rights approach and an insurance "group" approach. Those different approaches and their different impact on the concrete insurance premium of an insured, are described in the next two sections.

In view of a better understanding of the insurance "group" approach, the following section briefly summarizes some basic characteristics of insurance and clarifies why insurers use the subsidy-aversion argument as a justification of reducing subsidizing solidarity and accordingly as a justification to strive for equality between stereotype groups rather than between individuals. The main criticisms of this subsidy-aversion argument as related to risk-factors, mainly developed in economic literature, are analysed in the section entitled "Criticism of the Subsidy-Aversion Argument".

The hypothesis is made that these apparently different approaches to equality are reconcilable when the legislation banning discrimination, based on an open-ended system of justification (in the next section), enables the insurer to objectively and reasonably justify unequal treatment. The legal possibility of justification offers a reference frame for categorizing insurance classification schemes as discriminatory or not.

The key aim of the paper is to draw the basic boundaries of an analytical framework to integrate the stated subsidy-aversion criticisms into the legal justification test (last section).

\section{Two approaches to equality?}

The tension between an "individualistic" approach to equality, mostly upheld by lawyers, on the one hand, and a "group approach" to equality promoted by insurers on the other, clearly rose to the surface in the historic U.S. Supreme Court ruling in 
the two cases Manhart and Norris. Both cases concerned sex discrimination in occupational pension schemes.

In Manhart, ${ }^{3}$ the Court ruled that an annuity plan in which both sexes received equal periodic benefits at retirement, even though women paid larger contributions while working, was illegal. In 1983, the Supreme Court further held in Norris ${ }^{4}$ that the use of actuarial factors varying according to sex in terms of benefits under pension schemes was also caught by the prohibition of discrimination.

The ruling in these cases can be regarded as a first legal statement that insurance technique would not always be able to function as a safeguard to justify the difference in treatment between members of certain insurance classification groups. These cases resulted in a lively debate in American legal literature on sex discrimination in occupational pension schemes in particular, and discrimination in insurance in general, ${ }^{5}$ mainly based on the two different approaches and their implications for the principle of equality.

\section{"Individualistic" approach}

The individualistic approach to equality analyses fundamental rights, such as the right to equal treatment, in terms of individuals. Within this tradition, the right to equal treatment belongs to a person in his or her capacity as an individual and not in his or her capacity as a member of a racial, sexual, religious or ethnic group. An individual cannot be treated differently because of his or her membership in such a group, particularly in a group to which he or she has not chosen to belong. Although certain assumptions, that are to some extent accurate, can be true of women or men in general, they may not be true for each individual woman or man. ${ }^{6}$

In Manhart, the Court rejected the argument that fairness to an entire class would offset discrimination against the individual. The Court opined with regard to the concerned Equal Employment Opportunity Act of 1972: ${ }^{7}$

The statute makes it unlawful "to discriminate against any individual with respect to his compensation, terms, conditions, or privileges of employment, because of such individual's race, colour, religion, sex, or national origin". The statute's focus on the individual is unambiguous. It precludes treatment of individuals as simply components of a racial, religious, sexual, or national class. [...] Even if the statutory language were less clear, the basic policy of the statute requires that we focus on fairness to individuals rather than fairness to classes. Practices that classify employees in terms of religion, race or sex tend to preserve traditional assumptions about groups rather than thoughtful scrutiny of individuals.

${ }^{3}$ City of Los Angeles, Department of Water and Power v. Manhart (1978).

${ }^{4}$ Arizona Governing Committee for Tax Deferred Annuity and Deferred Compensation Plans v. Norris (1983).

${ }^{5}$ Gaulding (1995); Wortham (1986a, b); Ryan (1986); Abraham (1985); Benston (1983); Brilmayer et al. (1980, 1983); Benston (1982).

${ }^{6}$ Bartlett and Harris (1998, pp. 101-102).

${ }^{7} 42$ U.S.C.A. § 2000a. 
This approach is in accordance with the European Commission's earlier viewpoints ${ }^{8}$ and was also defended by Advocate-General Van Gerven in his conclusion to the joined cases of Neath, Ten Oever e.a. before the European Court of Justice, in which he quoted Manhart. ${ }^{9}$ There are also voices that are pointing at an implicit shift in EU equality legislation from the emphasis on a specific individual to an analysis of the relative impact of practices on different groups of persons. ${ }^{10}$ This shift is translated in a progression from "formal equality" towards "substantive" equality which "necessitates taking account of the existing inequalities which arise because a person belongs to a particular class of persons or to a particular social group". 11 Unlike formal equality, which precludes basing unequal treatment of individuals on certain differentiating factors such as gender, Tobler argues that the principle of substantive equality is based on the relevance of these differentiating factors in order to legitimize an unequal right. ${ }^{12}$ In fact these two approaches of equality legislation are complementary, since they both serve the same goal, which is securing equality between persons. ${ }^{13}$ The "individualistic" approach of equality, as it is described in this paper, contains both this formal and substantive perspectives of equality law.

\section{Group approach}

The insurance tradition, on the other hand, analyses risks, premiums and benefit schedules in terms of groups; most actuaries only consider individuals as members of a group. ${ }^{14}$ For example, it is gender differences and not individual differences that are taken into account to justify the difference in premiums, to explain the difference in benefits or to base a selection mechanism on. Unlike the "individualistic" human rights approach, insurance classification schemes rely on the assumption that individuals answer to the average (stereotypical) characteristics of a group to which they belong.

\section{Illustration of the different approaches: the gender factor in insurance contracts}

The different approaches to equality can be illustrated by the difference in treatment on the basis of gender in life insurance and motor-vehicle liability insurance.

\footnotetext{
${ }^{8}$ For example, in the initial Draft Proposal for a council Directive implementing the principle of equal treatment for men and women in occupational social security schemes, COM/83/217/def, O.J. C 134, May 21, 1983, 7.

${ }^{9}$ Van Schoubroeck and Thiery (2003, pp. 598-601); see also Schiek (2000, pp. 234-236).

${ }^{10}$ Bell (2004, p. 4); Fredman (2002, pp.108).

${ }^{11}$ These are the wordings of Advocate-General Tesauro in the European Court of Justice's Kalanke case (1995).

12 Tobler (2005, pp. 29-30).

13 Ibid.

${ }^{14}$ Brilmayer et al. (1980, p. 508).
} 


\section{Life insurance}

The difference in treatment between the male and female gender in the life insurance and annuities trade is best illustrated by the fact that members of one gender either have to pay a larger premium or receive fewer benefits than the other gender, on the basis that statistics show a higher average life expectancy for women than for men. ${ }^{15}$ As a result, annuity-benefit systems (rente viagère) and endowment insurance (assurance de capital différé) are far more favourable towards men than towards women, just as term life insurance (assurance décès) is far more favourable towards women. ${ }^{16}$

In using different mortality tables for males and females, life insurance companies want to ensure that one gender does not subsidize the other. In an annuity-benefit scheme, for example, where men and women, against payment of the same initial premium, are promised amounts on a periodic basis until the death of the annuitant, the insurer's goal is that the group of women should eventually receive the same total sum as the group of men. Because women on average live longer than men, women receive fewer benefits per period than men. The result is unequal treatment of individuals. Each man will receive a higher yearly benefit than each woman and an individual man with the same life span as an individual woman in total will have received a higher annuity sum. If men do not outlive their average life expectancy and women live to their average life expectancy, the total benefits paid to each of the two groups are equal. However, equality is not reached on an individual basis, since the contributions paid were not equal. If, in such cases, integrated (unisex) life-expectancy tables or loss-expectancy tables had been used (such unisex tables do not view members of a certain gender as members of a group of the same gender) the result would have been the opposite. Equality is then reached on an individual basis, but consequently the total benefits paid to each of the two groups are unequal. In this case one group would subsidize the other.

\section{Motor-vehicle liability insurance}

The difference between men and women as a "relevant" actuarial factor is not only used in annuity-benefit schemes or life insurance, but also in motor-vehicle liability insurance. Just as in the life insurance and annuities trade, the group approach to risks and the calculation of premiums run parallel to the aim of equality between the totality of men and the totality of women. In motor-vehicle insurance, insurance companies also want to ensure that one gender does not subsidize the other. In the hypothesis that females with a certain expected loss ratio (or "loss expectancy") would be charged an equally high premium as males with the same ratio (unisex loss-expectancy tables), men and women would be treated equally from an individual perspective. From a group perspective, however, women and men would not be treated equally, since women as a group would subsidize men as a group. Insurers indeed argue that

\footnotetext{
${ }^{15}$ Ruben and Elliot (1973, pp. 628-630).

${ }^{16}$ Anderson and Cowger (1985, p. 80).
} 
common statistics indicate that on average more women than men drive accident-free and consequently that the average woman has a lower loss expectancy than the average man. Based on these data, women are charged a lower premium than men.

\section{Conclusion}

These examples show that under a traditional actuarial approach, an individual belonging to a group with a higher statistical risk of survival or death ends up paying a higher premium or being paid fewer benefits. In motor-vehicle insurance, an individual belonging to a group that represents a higher statistical accident risk must pay higher premiums. For a typical "aleatory contract" as an insurance contract, this result is not surprising. To determine life expectancy or accident-loss probability of a single person, the average life expectancy or accident-loss probability of men as a group and women as a group is used. The individual is taken as a member of a group that he or she "belongs" to on the basis of his/her gender. These are clear examples of an insurance tradition that appears to have a different approach to equality and equal treatment by trying to achieve equality between groups, compared to the approach stemming from the civil rights tradition that strives for equality between individuals.

\section{Clarification of the insurance "group" tradition}

The examples above allow us to better understand the insurance companies' aim to preserve equality between groups and not between individuals and also the reasons why insurers think in terms of the average woman and the average man. Let us briefly clarify the insurance "group" tradition.

\section{Mutualization and chance solidarity}

One of the basic characteristics of insurance is "mutualization", which is the formation of groups. Fearing a heavy financial burden linked to the occurrence of a certain risk, a person pays a sum (called a premium) in exchange for the certainty (called "assurance") that the financial consequences will be limited, in the event that the insured risk occurs. The ideal situation would be that the obligations of the totality of small contributions of a group are statistically fully compensated for by the totality of the contributions made by this group. Consequently, mutualization (some speak in this context of "solidarity") is intrinsic to the classification of insurance risks. However, mostly it involves solidarity between those insured that have a same risk profile (with a comparable loss probability and loss extent). This means that those who are fortunate in the group - those that do not suffer damage - are co-payers for the unfortunate ones suffering damage. This solidarity is the so-called "pure chance solidarity" $" 17$ that can be regarded as the genuine insurance solidarity.

\footnotetext{
${ }^{17}$ Cousy (2002); De Pril and Dhaene (1998, pp. 118-120).
} 
196

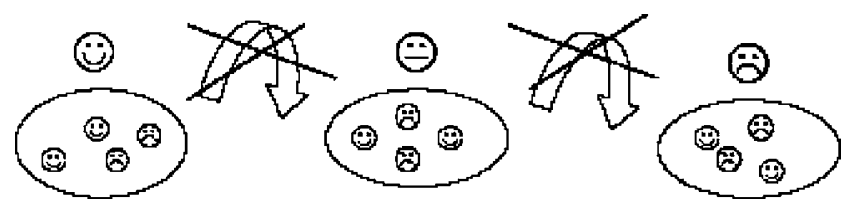

Figure 1. Chance solidarity within classification groups and subsidy aversion between higher and lower risks.

\section{Subsidizing solidarity and the subsidy-aversion argument}

Groups that, despite the insurer's efforts, do not consist of members with a comparable risk profile, give rise to the phenomenon of "subsidizing solidarity". In this situation, a person with a certain risk profile pays for the amount of loss of persons bearing a higher loss expectancy. Through the mechanism of adverse selection, subsidizing solidarity will be apt at threatening the financial stability of the insurance activity and of the insurer. It is always argued that an insured person would rather not contribute to people with a higher loss expectancy and does not like to see his/her premium rise for that reason. Therefore, if he is set a higher premium than the premium due for the risk he (assumes to) represent, he would leave the group. This is what is known as the "subsidy-aversion argument". ${ }^{18}$ This means that lower risks are averse to subsidizing higher risks (Figure 1).

The subsidy-aversion argument is often used as a justification for reducing subsidizing solidarity to chance solidarity and, in line with this, as a justification for the insurer to strive for equality between groups rather than between individuals.

Through increasing classification, insurers aim to decrease subsidizing solidarity as much as possible. The ultimate aim is to set a "just and fair" premium for each insured person. This means that, taking into account the economic efficient and possible risk factors, no group would be systematically placed either at a disadvantage or given preferential treatment. All groups should be treated equally and should not be subsidizing one another (Figure 2). ${ }^{19}$

\section{Criticism of the subsidy-aversion argument}

As previously mentioned, the legal justification of unequal treatment could function as the key to reconciling the different views on the concept of fairness: on the one hand the insurance "group" tradition striving for an equal (non-subsidiary) treatment between groups, and on the other, the "individualistic" human rights tradition striving for equal treatment between individuals. However, this legal possibility of justification can only play this reconciling role, if and upon the condition that at least certain criticisms against the subsidy-aversion argument are taken into account. The main criticisms concern: the controllability of risk factors by the (candidate-) insured; the causality between possible risk factors and the risk itself; the scepticism towards the

\footnotetext{
${ }^{18}$ Wils (1994, p. 456).

19 De Pril and Dhaene (1998, p. 120); Corlier (1998, p. 191).
} 


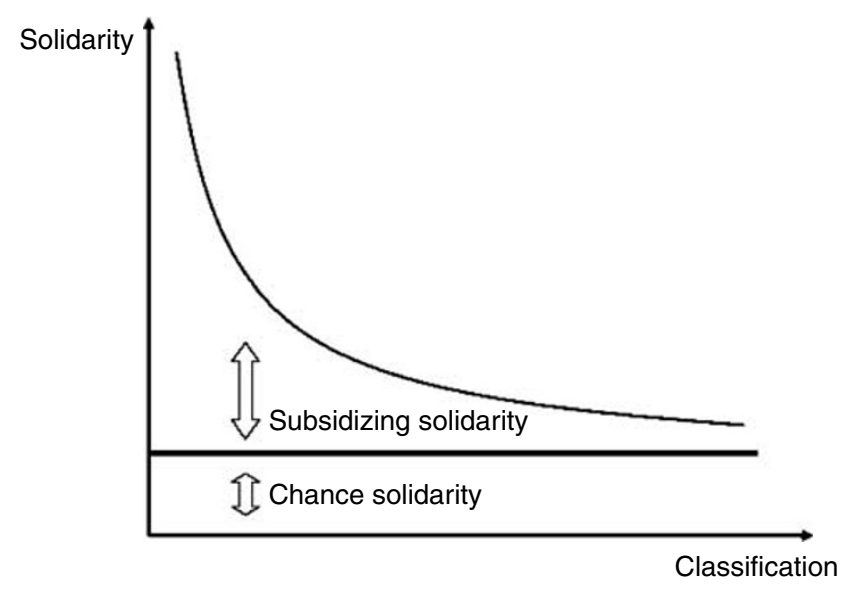

Figure 2. Decreasing subsidizing solidarity as a result of increasing classification by an insurer. Chance solidarity is not influenced by classification and remains at the same level.

phenomenon of adverse selection; the scepticism towards the welfare-improving effects of insurance classification and the tracing costs related to the search for more "realistic" risk-factors.

\section{Controllability}

The subsidy-aversion argument may seem fair in the case where risk factors that are controllable by the insured are involved. Examples of this would be the refusal to use fire-resistant building material, or engagement in careless smoking or risky sports. The insured can influence these factors by behaving in a risky manner or by reducing risks. By choosing one way or the other, he or she can become a member of a different group.

However, certain factors used for calculating premiums or benefits in insurance activity are immutable, that is, not under the control of the insured. Gender is one of the key examples of such a factor. No matter the effort, the insured will never be able to influence the loss expectancy at group level, nor can he or she become part of the other gender (by birth). This argument argues in favour of gender solidarity. In Frontiero v. Richardson, ${ }^{20}$ the U.S. Supreme Court described the gender factor as a suspect ${ }^{21}$ factor: "like race and national origin", it "is an immutable characteristic determined solely by the accident of birth" [...] "and what differentiates sex from such

${ }^{20} 411$ U.S. 677 (1973).

${ }^{21}$ The fact that a certain factor is "suspect" permits the Supreme Court to test it in a stricter manner (Strict scrutiny test), whether or not a distinction could be justified. Under a strict scrutiny test gender classification can only be justified by a compelling countervailing interest with no available alternative. Objectives such as administrative convenience and financial integrity would be scrutinized then more carefully. See Bailey et al. (1975, p. 811); Gerards (2002, pp. 509-510); Gray and Shtasel (1985, p. 91); Ryan (1986, p. 760). 
non-suspect statuses as intelligence or physical disability, and aligns it with the recognized suspect criteria, is that the sex characteristic frequently bears no relation to ability to perform or contribute to society".

As to the meaning and content of the concept of controllability, a Rawlsian definition of fairness could be taken into account. John Rawls suggested that the fairest distribution of assets would be the one which would have been chosen by potential beneficiaries before the natural lottery of endowments took place. ${ }^{22}$ In an insurance context, some authors have interpreted Rawls in a way that in "some" instances "controllability could outweigh statistical association and, for example, those suffering from disease, a genetic defect or disability on the basis of natural lottery should not be penalized in insurance". ${ }^{23}$ On the issue of genetic defectiveness however, some scepticism would be in place. Although research into behavioural genetics would suggest that genetic factors may also account for conditions such as alcoholism and nicotine addiction that have always assumed to be under one's control, some authors have argued that it would not be a fair solution if, for example, drinkers who are able to invoke a genetic predisposition for addiction could use genetic discrimination rules as a shield against higher insurance premiums while drinkers without such a mutation would be held accountable for their behaviour and would be at disadvantage. ${ }^{24}$

Thomas puts Rawls' definition of fairness in a broader perspective by using Rawls' "difference principle". He states that inequalities in society may be justified, provided that they make even the poorest members of society better off than they otherwise would have been. Thomas argues that the poorest individuals in most societies are mostly the sick and disabled and finds it difficult to see "how their exclusion from insurance risk pools can be said to make them better off than they would otherwise have been". 25

\section{Causality}

A second criticism of the subsidy-aversion argument is the not-unimaginable absence of a direct causal link between possible risk factors (such as gender) and the risk itself.

It is often stated that there is no scientifically proven, apparent causal link between gender and mortality. ${ }^{26}$ Gender does not predict longevity in individual cases because the explanatory variable is mostly behaviour. ${ }^{27}$ It will rather be correlations as for instance between smoking behaviour and mortality, that can actually reflect a causal relationship. ${ }^{28}$ Characteristics such as income and occupation can also be very significant in determining life expectancy. ${ }^{29}$

\footnotetext{
${ }^{22}$ Rawls (1999, pp. 11-17); Wagner (2003); Gollier (2002, p. 825); Abraham (1985, p. 437).

${ }^{23}$ Wortham (1986b, p. 884).

${ }^{24}$ Lemmens (2000, p. 376).

${ }^{25}$ Moultrie and Thomas (pp. 4-5).

${ }^{26}$ Wils (1994, p. 456).

${ }^{27}$ Brilmayer et al. (1983, pp. 530-532); see COM (2003).

${ }^{28}$ Still, smoking behaviour is only one among many causes that can explain only part of the occurrence.

${ }^{29}$ McDonald (2003).
} 
When it comes to motor-vehicle insurance, studies on the causation of variances in driving statistics by gender have long suggested that mileage driven, the number of prior traffic violations, and other "behavioural" risk determinants ${ }^{30}$ explain the difference in insurable risk, rather than the driver's gender, ${ }^{31}$ although, it is suggested that gender would have higher "predictive value" in motor-vehicle liability insurance than in life insurance. ${ }^{32}$

On the one hand, the concept of causality has already been used in theories presented to define whether the use of certain risk classifiers is fair. According to Gaulding, the use of a classifier is to be considered as generally fair if it is correlated with a risk, except in the situation where the classifier does not seem to be causally connected to the risk factor (or highly suspect, having been the basis for extensive societal discrimination). "Statistical association" Wortham writes, "should only be seen as a somewhat necessary, but not a sufficient criterion for permissible use of classification." "33 This concept of fairness has nothing to do with immutability or controllability. "While we can agree," suggests Gaulding, that people do not control factors such as gender, while they do control risk factors such as smoking, there lie numerous other factors between these two extremes that are more difficult to characterize, so that the question whether a factor is controllable is not a factual but a normative question". A person can, for instance, be a bad driver because his or her impoverished circumstances did not permit the normal training and practice. ${ }^{34}$

On the other hand, causality, as far as it could be (statistically) determined, will not per se lead to a fair solution, so that controllability has still got an important role to play in considerations of fairness in insurance classification. Abraham gives the example of drivers with a congenitally slow "reaction time" that may be a cause of accidents, but not within the control of these drivers so that it would not be acceptable to charge these drivers a higher premium. ${ }^{35}$

\section{Scepticism of adverse selection}

Further, it is argued that the danger of adverse selection, supporting the subsidyaversion argument, is not (always) realistic. Adverse selection will not occur in situations where there are no existing alternatives for insurance or where the insurance coverage is highly necessary or compulsory by law (e.g. motor-vehicle insurance ${ }^{36}$ ). In these cases, the market is rather price-inelastic. Health insurers claim that a ban on, for instance, genetic discrimination will lead to an adverse-selection spiral. However, this

${ }^{30}$ Schwarze and Wein $(2005$, p. 17) argue that the use of such 'behavioural risk determinants will even function as an incentive for safe driving behaviour'.

${ }^{31}$ Ryan (1986, p. 765).

32 Ibid. (p. 758).

${ }^{33}$ Wortham (1986a, p. 418; 1986b, p. 883).

${ }^{34}$ Gaulding (1995, p. 1680).

35 Abraham (1985, p. 437).

${ }^{36}$ Schwarze and Wein $(2005$, p. 5), who contend that the gain of low-risk consumers, as a consequence of risk classification, does not accrue in a mandatory fixed coverage scheme of insurance (as for instance the mandatory third-party motor) insurance (TPMI) of Germany, but will do in a Rothschild-Stiglitz adverse selection market. 
is found to be unlikely to happen since the low-risk insured cannot leave the insurance market without foregoing health care. ${ }^{37}$

In the economic literature ${ }^{38}$ it is stated that perfect inelastic demand (a demand for insurance that is not influenced by the price to be paid) insures that there is no adverse selection and thus no efficiency loss from pooling different risk types (by definition, since, with an inelastic demand curve, demand for insurance is always the same whatever the price).

\section{Welfare-improving classification?}

Moreover, the economic literature states that when the cost of differentiation is taken into account, subsidy aversion is only at stake under certain assumptions that are not necessarily welfare-improving.

In markets with price-inelastic demand, on the one hand, differentiation can be welfare-improving, but only for the low-risk insured and only if the per-person cost per test to determine who is high- and who is low-risk (cost of tracing) is lower than the subsidy ${ }^{39}$ that each member of a low-risk group would pay with pooling. The total welfare (for low-risk insured, high-risk insured and for insurers), however, will fall due to the extra cost of the test.

On the other hand, in a market with an elastic demand, total welfare will be able to rise due to differentiation but only on the condition that the total cost of differentiating is lower than the efficiency loss ${ }^{40}$ from pooling, borne by both the insured and insurers. ${ }^{41}$ Assuming that the low-risk insured bear the cost of differentiation, ${ }^{42}$ the insured will decide whether there will be differentiation or not. ${ }^{43}$ The low-risk insured will only take account of his or her own welfare gain or loss after differentiation, without taking into account the welfare gain or loss for the rest of the community (the high-risk insured and the insurers). As a result, differentiating might be welfare-improving for the low-risk insured but not for the community as a whole (insurers and high-risk insured included). ${ }^{44}$

\section{Tracing costs}

The preference for certain risk-classification factors, such as gender or age, above others is highly dependent on practical and economic reasons. Still, the loss probability of a person could have been very different if other characteristics had

${ }^{37}$ Gaulding (1995, p. 520).

${ }^{38}$ Borenstein (1989, p. 26).

${ }^{39}$ Subsidy is, within this term, a decline of consumer surplus.

${ }^{40}$ Efficiency loss in terms of low risks that are too little insured and high risks that are too much insured (adverse-selection effects of pooling).

${ }^{41}$ Borenstein (1989, pp. 26-29); Faure and Van den Bergh (1989, pp. 127-128).

${ }^{42}$ Which is not unrealistic, since only the low risks can gain from differentiation.

${ }^{43}$ Gollier (2003, p. 78).

${ }^{44}$ See Hoy (1982, p. 321), for an in-depth analysis of the welfare implications of (imperfect) risk categorization. 
been considered. ${ }^{45}$ The factor of gender, for example, is often used because it is easier to trace or because administrative costs of tracing are lower, ${ }^{46}$ although it is known that more realistic but more hidden factors actually underlie the risk. ${ }^{47}$ This would make the subsidy-aversion argument incomplete. Why would a man with a higher life expectancy want to contribute to women with a lower life expectancy, apart from altruism or love? In line with the subsidy-aversion logic, a man and a woman with the same life expectancy should actually pay the same premium or receive the same benefits. But because of the use of gender classification they are treated differently. The same is true, for instance, for young males paying much higher liability insurance premiums than other drivers while it is possible that drunken driving by young males causes a high percentage of all car accidents and only a small percentage of all young males drive while drunk. ${ }^{48}$ In this example, developed by Abraham, a junior and a senior driver with the same chance of having accidents are charged different prices so that the cost of inaccurate classification is borne by just a small group of all those insured. ${ }^{49}$

\section{The prohibition on discrimination and the possibility of justification}

Legislation banning discrimination that provides the insurer with the option of justifying a classification or selection based on a specific characteristic embeds the key to bridge the above-clarified insurance "group" approach and "individualistic" human rights approach to the principle of equality. Analysis of the different regulations reveals that the prohibition on discrimination based on certain risk factors can be imposed to varying degrees. Although several variations are possible concerning the legal option of justifying unequal treatment, two basic systems can be distinguished: one defined as a close-ended system and the other as an open-ended system of justification.

If the applicable legal system permits a classification or distinction to be justified, this justification needs to meet certain tests on the basis of which it can be decided whether the distinction is objective and reasonable.

\section{Varying degrees of prohibitive discrimination}

\section{Close-ended system of justification}

The key feature of a close-ended system is that direct and indirect discrimination are unconditionally prohibited, with specific statutory exceptions. Since such statutory

\footnotetext{
${ }^{45}$ Wortham (1986b, p. 883).

${ }^{46}$ Brilmayer et al. (1980, p. 518), Benston (1982, p. 496).

${ }^{47}$ The U.S. Supreme Court in Manhart stated: "Treating different classes of risks as though they were the same for purposes of group insurance is a common practice that has never been considered inherently unfair. To insure the flabby and the fit as though they were equivalent risks may be more common than treating men and women alike; but nothing more than habit makes one 'subsidy' less fair than the other'.

48 Abraham (1985, p. 431-432).

${ }^{49}$ Ibid.
} 
provisions are exceptions to a general ban, they need to be interpreted in a restrictive manner.

In a mitigated variation to the straight or pure "close-ended system", a system can allow for a general ground of justification that is limited to the cases of indirect difference in treatment. Such an exception can, for instance, be formulated as "an objective and reasonable justification" of the distinction made. The Netherlands, ${ }^{50}$ France $^{51}$ and the United Kingdom ${ }^{52}$ have adopted such a system. Moreover, the recent European Directive Sex Discrimination Goods and Services can be categorized under this variation of a close-ended system. However, this Directive is broader by granting Member States the option to decide before 21 December 2007 whether proportionate differences in an individual's premiums and benefits where the use of sex is a "determining factor in the assessment of risk based on 'relevant' and 'accurate' actuarial and statistical data", are permitted (Article 5, 2). The European legislator leaves it up to the Member States to assess a more liberal discrimination policy towards insurance undertakings, by offering these Member States the option of implementing a specific definition of (direct and indirect) discrimination regarding insurance services. At first sight, this concession to the insurance sector allows insurers to differ on the basis of the uncontrollable factor of gender. Whether this classification based on the gender factor can be sustained shall, however, depend on the application in each individual case. Indeed, insurers must not only compile and provide the accurate data, but the question also remains how judges will interpret the meaning and

${ }^{50}$ The Netherlands have a general Anti-discrimination Act (2 March 1994) prohibiting direct and indirect discrimination on the basis of a limited number of criteria, such as gender, race and sexual orientation. Indirect differences in treatment can be given an objective and reasonable justification, but a direct difference in treatment is only acceptable when it is statutorily provided. For the gender factor, direct differences in treatment are only accepted in cases where the gender factor is "decisive", in case of preferential treatment of women and in cases concerning the protection of women, notably in relation to pregnancy and motherhood. See Articles 2-3 at http://www.cgb.nl/english/asp/awgb.asp; see Vrielink (2003b, pp. 764-765). In labour relations, Dutch law also provides for a close-ended system, by way of the Equal Opportunities Act of 1 March 1980 (http://www.cgb.nl/asp/wgb.asp) and the Equal Working Hours Treatment act of 3 July 1996. (http://www.cgb.nl/asp/woa.asp).

${ }^{51}$ French law provides for a close-ended system, through the application of Article 225 of the French Criminal Code and Article 122-1 of the Customers Code. No distinction is made between direct and indirect discrimination. Article 225 of the Criminal Code penalizes discrimination on a number of criteria, including gender. It is not applicable to a few situations, such as the state of health with regard to the coverage of risks (insurance), or gender in labour relations. See Article 1, Act no 2001-1066 of 16 November 2001, Official Journal of 17 November 2001. Article 122-1 of the Customer code forbids the refusal to sell a product or the delivery of a service, without a legitimate reason (no matter the criterion used). See http://www.legifrance.gouv.fr/html/codes_traduits/consolegtextA.htm and Article 13, Act no 2001-1168 of 11 December 2001 IV 30, Official Journal of 12 December 2001. See Durry (2001, p. 67).

52 The UK enacted the Sex Discrimination Act in 1975. See http://www.eoc.org.uk/cseng/legislation/ sda.pdf. This Act prohibits sex discrimination against individuals in the areas of employment, education and the provision of goods, facilities and services and in the disposal or management of premises. The Act provides for some exceptions, justifying sex discrimination. This is inter alia the case with regard to insurance where it is proven that the discriminatory treatment reasonably relates to actuarial or other data (Article 45). However, a distinction is made between direct and indirect discrimination, where only indirect discrimination is justifiable. For an overview of this act, see http://www.eoc.org.uk/cseng/ legislation/the_sex_discrimination_act_an_overview.asp 
content of the terms "relevant" and "accurate" actuarial and statistical data in a particular case.

\section{Open-ended system of justification}

The key characteristic of an open-ended system is that, in spite of the prohibition on discrimination, the person who must account for a difference in treatment based on gender is left with the option of claiming that the distinction he or she made can be objectively and reasonably justified. This system thus grants an option of implementing a justification test. The justification test would be allowed for differences directly or indirectly based on gender, health and age, etc. An open-ended system will, more than a close-ended system, allow for the concept of discrimination to evolve. It also prevents certain situations from being overlooked in defining statutoryprovided exceptions. The Belgian Anti-discrimination Act of 25 February 2003 can be regarded as an example of an open-ended system. ${ }^{53}$ The impact of this act on insurance services in particular is considerable since it forbids (as interpreted by the Belgian Constitutional Court ${ }^{54}$ ) discrimination on the basis of any characteristic whatsoever.

As mentioned above, by permitting proportionate differences in individual's premiums and benefits where the use of sex is a "determining factor in the assessment of risk based on relevant and accurate actuarial and statistical data", the European Directive Sex Discrimination Goods and Services could also be recognized as an openended system with regard to insurance classification matters related to gender.

\section{Justification test}

The justification test to deal with the alleged discriminatory character of unequal treatment has been developed in a very rich array of case law of inter alia the European Court of Justice, ${ }^{55}$ the European Court of Human Rights ${ }^{56}$ and national constitutional courts. ${ }^{57}$ This case law bases the justification test commonly on the concept of a

${ }^{53}$ Belgium, like The Netherlands, enacted on 25 February 2003, Belgian State Gazette 17 March 2003, a general Anti-discrimination Act that forbids direct and indirect discrimination on the basis of a limited number of criteria, among which are race, sex, state of health or wealth. This Act offers the possibility for both direct and indirect differences in treatment, to give a (reasonable and objective) justification. When no such justification is possible, the difference in treatment constitutes a prohibited discrimination. See Thiery (2003); Vrielink (2003a, b).

${ }^{54}$ Court of Arbitration no 157/2004, 6 October 2004, Belgian State Gazette 18 October 2004, 72.389, recital B.15.

${ }^{55}$ For example, ECJ 13 May 1986, case 170/84, Bilka, ECR 1986, 1607; ECJ 1 July 1986, case 237/ 85, Rummler, ECR 1986, 2101; Teulings; ECJ 31 March 1981, case 96/80, Jenkins, ECR 1981, 911; ECJ 27 October 1993, case C-127/92, Enderby, ECR 1993, I-5535.

${ }^{56}$ For example, ECHR 28 May 1985, Abdulaziz, Series A, vol. 94 (very weighty reasons-doctrine).

${ }^{57}$ For an overview of the criteria of the test in the case law of the Belgian Constitutional Court, see De Baets (2001, pp. 104-105); Suetens (1990); See also the ruling in the Canadian Supreme Court in "Zurich Insurance Co v. Ontario Human Rights Commission", http://www.canlii.org/ca/cas/scc/1992/ 1992scc64.html, where the Court had to rule on the "reasonable and bona fide character" of discrimination against young, single, male drivers in the calculation of automobile insurance premiums by the Zurich Insurance Co. 
difference in treatment that can be "objectively justified by a legitimate aim and the means of achieving that aim are appropriate and necessary". This multi-stage test is comprised of different, accumulatively applicable criteria. ${ }^{58}$ When one of these tests is not met, the unequal treatment concerned (distinction, classification, differentiation) will be determined to be discriminatory. These accumulatively applicable criteria can be briefly described as follows:

- Legitimacy test: Was the distinction, classification or differentiation made in pursuit of a legitimate aim? The aim of the distinction or classification has to be consistent with national and international law and its pursuance has to fulfil a genuine need of the defendant.

- Objectivity test: Is the distinction or classification based on an objective element? We are talking about factual elements that are knowable and of which the existence is not disputed, such as body-mass index, age and place of residence.

- Pertinency test: Is the distinction relevant in relation to the aim pursued? The unequal treatment has to constitute an effective means to achieve the aim pursued.

- Less restrictive alternative test: Can the distinction be generally regarded as a necessary or indispensable means to attain the aim pursued? This implies an investigation as to the availability of less burdensome alternatives to the distinction made and it should also be ascertained whether the defendant could have been expected to opt for one of the alternatives.

- Proportionality test: Is the distinction proportionate? It has to be ascertained whether the defendant has reasonably balanced the interests that are served by the distinction against the interests that are impaired by the distinction. This balancing should not be arbitrary. ${ }^{59}$

It must be noted that these tests result from extensive case law that has been developed in a context of a vertical application of the prohibition on discrimination, that is, in the relation between the State and its citizens. In a horizontal relation, that is, in the mutual relation between citizens (private parties), a Court can perhaps test in a more neutral or marginal manner. Private parties can indeed not be expected to act in the same manner as a government. After all, private parties such as insurance companies pursue an aim of self-interest, whereas governments generally seek a general (welfare-improving) goal.

Therefore, a too far-reaching opportunity control by the Court seems unsuitable in horizontal relations, except for situations where private parties are taking up tasks that traditionally belong within the competence of the state (for instance, health insurance).

\section{Implications of the prohibition of discrimination with regard to insurance technique}

By enacting legislation prohibiting gender-based discrimination in the access to and supply of insurance, the legislator does not want to rule on the merits of the reduction of subsidizing solidarity as such, nor does he want to rule on the application of

\footnotetext{
${ }^{58}$ Gerards (2002, pp. 727-729).

${ }^{59}$ Van Schoubroeck and Thiery (2005, p. 46).
} 
actuarial calculations based on statistics. However, what the legislator does want to rule upon is the mode and the criteria upon which subsidizing solidarity is reduced. By doing so, the legislator has a direct impact on the mode and the criteria upon which insurance classifications are based.

Let us take the example of the new European Directive Sex Discrimination Goods and Services. In principle, the Directive prohibits the use of gender in calculating premiums and benefits for the purpose of insurance and related financial services in all new contracts concluded after 21 December 2007. One could say that the European legislator has taken the approach of individual equality between people, providing for the use of gender-neutral factors as a basic principle in the supply of insurance. Not surprisingly, it is only for factors such as gender, that are not controllable and not mutable, that the European Community desires a subsidizing solidarity between (gender) groups that currently are equated with higher and lower risks.

An immediate consequence of the prohibition of classification in insurance on the basis of certain (suspect) factors is that an insurer will have to find other (less burdensome) classifiers that are still actuarially sound. This might result in increased costs to both insurers and insured: a rise in premiums for a substantial number of individuals belonging to a formerly low-risk classified group (e.g. women in motorvehicle liability insurance), insurers coping with an added financial burden of unfunded liabilities and a substantial rise in administrative costs implementing this prohibition. However, the economic impact of such a regulation depends on the type of market in which insurance is supplied. Ryan finds evidence that the consequences mentioned are more likely to occur in the context of life insurance than in motorvehicle liability insurance ${ }^{60}$. Schwarze and Wein clarify that the costs of prohibiting the use of, for example, gender as a classifier seem smaller in mandatory insurance as compared to deregulated markets. ${ }^{61}$ Apart from the observation of market-type influence, one could also expect differences between the long-term and short-term economic effects of the prohibition to take certain characteristics into account.

\section{Implications of the prohibition of discrimination with regard to other human rights}

The prohibition of using risk factors such as gender or age could, apart from an increased level of equal treatment of individuals, also have a rather negative side-effect with respect to the field of privacy-concerns. Let us take an example from motorvehicle liability insurance. The factor of driving experience in motor-vehicle liability insurance is a more direct cause of loss than the factor of gender or age. Still, this factor is highly subject to errors or fraud and therefore scarcely controllable for the insurer. To increase the level of control, the insurer could provide insurance coverage on the condition of installing some kind of "black box" in the vehicle. This box could register data about the distance covered, area and locations, frequency or time of travelling. Nevertheless, from the perspective of the insured, this controlling mechanism may infringe on his or her fundamental right to privacy. The same is

\footnotetext{
${ }^{60}$ Ryan (1986, pp. 760-761).

${ }^{61}$ Schwarze and Wein (2005, p. 19).
} 
true for the use of demerit points as weights for individual traffic violations to calculate premiums, for example. ${ }^{62,63}$ These examples illustrate the delicate balance between various civil rights of the insured and the interest of the insurer.

\section{Integration of the subsidy-aversion criticisms in the justification test}

Legislation that permits an objective and reasonable justification for certain differences in treatment of the (candidate) insured by insurers is able to bridge the earlier clarified conflict between "group" and "individualistic" approaches to equality, instead of polarizing these approaches. Our argument is that the above-mentioned criticisms of the concept of subsidy aversion (supra, V) play a key role in a viable justification test to be met to rebut the discriminatory character of an insurance classification system. The following analysis attempts to integrate these criticisms into the different criteria of the multi-stage test. We focus in particular on the legitimacy test (A), the pertinency test (B), the less restrictive alternative test (C) and the proportionality test (D).

As mentioned, the concerned justification test has primarily been developed in cases relating to vertical relations, that is, the relations between states and their citizens. Much debate has taken place as to how this test could be applied in horizontal relations, that is, the mutual relations between citizens (private parties). In particular, it has been observed that the concept of an objective and reasonable justification should be interpreted much more flexibly when applied in horizontal relations, ${ }^{64}$ such as the provision of goods and services between an insurer and an (candidate) insured and its application to insurance classification. ${ }^{65}$

\section{Legitimacy test}

As to the legitimate aim that must be established by an insurer who has to rebut the discriminatory character of its classification system, we already argued that an aim of self-interest (or at least to fill an economic need) could suffice to comply with the legitimacy test. The legitimate aim pursued by maintaining a system of insurance classification on the basis of, for example, (suspect) factors such as gender, health or age can indeed lie in safeguarding the insurer's financial stability, which would inevitably be disturbed if a certain classifier could not be used. The subsidy-aversion argument can be usefully invoked in this discussion. If the higher risks are paying a premium that is inaccurately reflecting their actual risk, the insurer's financial stability would, through the mechanism of adverse selection, be endangered.

Still, there are certain limitations on how far an insurer can go in justifying its classification system. The argument directly boils down to the above-mentioned

\footnotetext{
${ }^{62}$ An example would be the German Demerit Point System (DPS); Schwarze and Wein (2005, p. 17).

${ }^{63}$ Although demerit points exist in many countries, even in countries where the use of photo-radar and mailing of speeding-tickets is often seen as a violation of privacy.

${ }^{64}$ Gerards (2002), Velaers (2003, pp. 307-308).

${ }^{65}$ Van Schoubroeck and Thiery (p. 606).
} 
criticisms of subsidy aversion. When the legitimacy test is being scrutinized, the necessary scepticism of adverse selection should be considered, in particular when price-inelastic markets are concerned. Moreover, the claim that the classification system used can be welfare-improving should be considered under the correct premises as clarified.

\section{Pertinency test}

The pertinency test should also be met in order to rebut the alleged discriminatory nature of insurance selection and/or classification. The criticisms based on both causality and controllability, perfectly fit within the pertinency test. This test requires the applied classification system to be relevant ${ }^{66}$ Consequently, only those factors that have an (direct) impact on the nature of the insured risk can be used and the premium paid should be an equation of the expected cost. ${ }^{67}$ Complying with this pertinency test requires insurers to prove based on statistics that show a correlation between a certain characteristic and the risk insured. Pure statistical correlations, however, will not always suffice. To a certain degree, an insurer will have to show that the classifiers used in the classification system applied are connected in a causal relation to the risk insured, or at least can predict or affect it. Nevertheless, in assessing the criteria in an individual case the court should also consider that even if it is statistically valid to differentiate on the basis of certain characteristics, they are not always controllable by the insured. As already stated, an appraisal on the basis of controllability of the characteristic will, mostly, be of a normative character.

\section{Less restrictive alternative test}

It occurs that in an insurer's classification system certain characteristics are used that are easy to trace and/or easy to administer while more realistic but more hidden factors actually underlie the risk. In Frontiero v. Richardson ${ }^{68}$ the U.S. Supreme Court ruled that drawing a sharp line between immutable factors such as gender, solely for the purpose of achieving administrative convenience, is an arbitrary choice and cannot be a justification for dissimilar treatment of those who are similarly situated. This criticism of the subsidy-aversion argument perfectly fits in with the less restrictive alternative test. Indeed, this test evaluates the availability of less burdensome alternatives to the distinction made.

For instance, the use of mileage, occupation, house ownership or other "behaviour risk determinants" in motor-vehicle liability insurance could be a more equitable and still actuarially sound rating practice. ${ }^{69}$ Equally lifestyle-related factors would make it possible to classify more accurately in life insurance. ${ }^{70}$ An increased use of deductibles

\footnotetext{
${ }^{66}$ Thiery (2003, pp. 60-61); Van Drooghenbroeck and Van Drooghenbroeck (2004); Bernauw (2004); Paris (2004).

${ }^{67}$ Abraham (1985, p. 429).

${ }^{68}$ Frontiero v. Richardson (1973).

${ }^{69}$ Ryan (1986, pp. 762-763).

${ }^{70}$ Wils (1994, p. 459).
} 
(as a form of co-insurance) could also be a less restrictive alternative and an effective means of combating adverse selection effects. It is argued that the rise in a deductible level increases the effective insurance costs paid by the high-risk insured, while the effective insurance cost paid by the low-risk insured constrains, so that the low-risk insured will choose to stay in an insurance pool. ${ }^{71}$

\section{Proportionality test}

The proportionality test is the ideal tool to balance the interests that are served and the interests that are impaired by insurance classification. In its assessment of this test, the court could take into account the specific social function a private insurer fulfils with regard to some forms of necessary insurance coverage. For instance, in private health insurance, due to a decline in social security, European insurance companies are taking up tasks that traditionally fell within the competence of the state. Other examples of insurance considered as indispensable are mandatory motor-vehicle liability insurance, certain forms of life insurance, ${ }^{72}$ or occupational pension schemes. The private insurer should balance the indispensable character of insurance coverage against his own selfinterest.

The proportionality test needs to be cumulatively applied with the other tests in the justification of insurance classification. This may imply that the use of the classifier can still be discriminatory if a particular interest is at stake, even if the insurance classifier is more or less controllable by the insured and a causal (or predictive) relation can be established between the classifier and the insured risk. This interest can be broader than the insured's individual interest to obtain necessary insurance. It could well be an interest that society as a whole considers an interest to be preserved and protected, regardless of the economic or political consequences. This can be illustrated by the issue of pregnancy as a risk variable in private health insurance. Although it can be proven that a pregnant woman consumes more health insurance than the average woman, it cannot be denied that society in general benefits from procreation. Consequently, it would not be proportionate to place the major costs of procreation entirely on one group - pregnant women - and impose unfair disadvantages on them. This point of view is emphasized in EU legislation. Indeed, the European Directive Sex Discrimination Goods and Services unconditionally forbids, that is, without any form of justification, less favourable treatment of women for reasons of pregnancy and maternity. ${ }^{73}$

\section{Concluding observation}

In this paper, it is argued that the contradiction between an "individualistic" human rights tradition and an insurance "group" tradition of fairness and equality is, in fact, only an apparent one on the condition that the concept of subsidy-aversion by the

\footnotetext{
${ }^{71}$ Faure and Van den Bergh (1989, p. 128); Priest (1987, p. 1572).

${ }^{72}$ For instance, term life insurance against the debtor's death.

${ }^{73}$ See article 4, 1 and 3 and article 5, 3 of the Directive.
} 
insured is assessed within its real meaning and limits. Taking into account certain criticisms of the use of subsidy aversion as an argument pro-risk classification on the basis of certain characteristics such as gender, age or health, the legal possibility of justification of unequal treatment could function as the key to reconciling these different views on fairness in insurance classification and to bridge the insurance "group" tradition and the "individualistic" human rights tradition. Instead of denying a sane insurance activity, this regulation banning discrimination could, in itself, be regarded as a tool to achieve a reasonable balance between the dual goals of actuarial validity and social fairness.

\section{References}

Abraham, K.S. (1985) 'Efficiency and fairness in insurance risk classification', Virginia Law Review 71: 403-451.

Anderson, R.A. and Cowger, C.N. (1985) 'Discrimination in insurance: The unisex issue', Washburn Law Journal 24: 78-98.

Arizona Governing Committee for Tax Deferred Annuity and Deferred Compensation Plans v. Norris (1983) 463 U.S. 1073.

Bailey, H., Hutchison, T. and Narber, G. (1975) 'The regulatory challenge to life insurance classification', Drake Law Review Insurance Law Annual 4: 779-827.

Bartlett, K. and Harris, A. (1998) 'Gender and Law: Theory, Doctrine, Commentary', from http:// academic.udayton.edu/gender/02Unit/index.htm, pp. 101-102.

Bell, M. (2004) The concept of equality, Presentation to the seminar 'Fight against discrimination: the race and framework Emplyment Directives', Trier, 1-2 October 2004, http://www.era.int/web/en/resources/ 5_2341_896_file_en.1171.pdf, pp. 1-9.

Benston, G. (1982) 'The economics of gender discrimination in employee fringe benefits: Manhart revisited', The University of Chicago Law Review 49: 489-538.

Benston, G. (1983) 'Discrimination and economic efficiency in employee fringe benefits: A clarification of issues and a response to professors Brilmayer, Laycock and Sullivan', The University of Chicago Law Review 50: 250-279.

Bernauw, K. (2004) 'De Wet bestrijding discriminatie en verzekeringen', in E. Brems and M. De Vos (eds) De Wet bestrijding discriminatie in de praktijk, Antwerp: Intersentia, pp. 277-303.

Borenstein, S. (1989) 'The economics of costly risk sorting in competitive insurance markets', International Review of Law and Economis 9: 25-39.

Brilmayer, L., Hekeler, R.W. and Laycock, D. (1980) 'Sex discrimination in employer-sponsored insurance plans: A legal and demographic analysis', University of Chicago Law Review 47: 505-560.

Brilmayer, L., Laycock, D. and Sullivan, T. (1983) 'The efficient use of group averages as nondiscrimination: A rejoinder to professor Benston', The University of Chicago Law Review 50: 222-279.

City of Los Angeles, Department of Water and Power v. Manhart (1978) 435 U.S. 677, 710.

COM (2003) Explanatory Memorandum, Proposal Directive Sex Discrimination Goods and Service, 657, IV, pp. 6-7.

Corlier, F. (1998) 'Segmentation: Le point de vue de l'assureur', in H. Cousy, H. Claassens and C. Van Schoubroeck (eds) Competitiviteit, ethiek en verzekering, Reeks CRIS, 10, Antwerp: Maklu - Academia Bruylant, pp. 190-204.

Council Directive (2004) Directive 2004/113/EC of 13 December 2004 implementing the principle of equal treatment between men and women in the access to and supply of goods and services, O.J. L 373, 21 December 2004, 37.

Cousy, H. (2002) 'La segmentation dans l'assurance de la responsabilité civile', in B. Deffains (ed) L'analyse économique du droit dans les pays de droit civil, Actes du colloque Nancy, 28 et 29 juin 2000, Paris: Editions Cujas, pp. 181-190.

De Baets, G. (2001) 'Het gelijkheidsbeginsel in het kader van de rechtspraak van het arbitragehof', in F. Moeykens (ed) Praktijkjurist, Ghent: Academia press, pp. 3-36. 
210

De Pril, N. and Dhaene, J. (1998) 'Commission des Assurances - Rapport du groupe de travail segmentation', in H. Cousy, H. Claassens and C. Van Schoubroeck (eds) Competitiviteit, ethiek en verzekering, Reeks CRIS, 10, Antwerp, Maklu -Brussels: Academia Bruylant, pp. 110-139.

Durry, G. (2001) 'La sélection de la clientèle par l'assureur: aspects juridiques', Risques 45(March): 65-71.

European Court of Justice (1995) Case C-450/93, Kalanke, ECR 1995, I-305.

Faure, M. and Van Den Bergh, R. (1989) Objectieve aansprakelijkheid, verplichte verzekering en veiligheidsregulering, Antwerp, Maklu: Series Recht en Economie.

Fredman, S. (2002) Discrimination Law, Oxford: Oxford University Press.

Frontiero v. Richardson (1973) 411 U.S. 677.

Gaulding, J. (1995) 'Race, sex and genetic discrimination in insurance: what's fair?' Cornell Law Review 80: 1646-1694.

Gerards, J.H. (2002) Rechterlijke toetsing aan het gelijkheidsbeginsel, The Hague: Sdu Uitgevers.

Gollier, C. (2002) 'La solidarité sous l'angle économique', Revue Générale du Droit des Assurances 3 Assurance et solidarité, Colloque du 10 novembre 1999, pp. 824-830.

Gollier, C. (2003) 'Analyse économique de l'assurabilité', Risques 54(June): 75-80.

Gray, M.W. and Shtasel, S.F. (1985) 'Insurers are surviving without sex', American Bar Association Journal 71: 89 .

Hoy, M. (1982) 'Categorizing risks in the insurance industry', The Quarterly Journal of Economics 97(May): 321-336.

Lemmens, T. (2000) 'Selective justice, genetic discrimination, and insurance: should we single out genes in our laws?', Mc Gill Law Journal 45: 347-412.

Mcdonald, O. (2003) Sex discrimination and annuities, Presentation at the public hearing on 'sex discrimination outside the workplace' at the European Parliament, http://www.europarl.eu.int/ hearings/20030910/femm/mcdonald.pdf, 10 September 2003, pp. 1-7.

Moultrie, T.A. and Thomas, G. 'The right to underwrite? An actuarial perspective with a difference', http:// www.guythomas.org.uk/pdf/rtu.pdf.

Paris, C. (2004) 'Segmentation et sélection des risques', in J. Rogge (ed) Les paramètres de sélection des risques à l'aube du XXIème siècle, Bulletin des Assurances, Dossier 10, Malines: Editions Kluwer, pp. 57-88.

Priest, G.L. (1987) 'The current insurance crisis and modern tort law', The Yale Law Journal 96: 1521-1590.

Rawls, J. (1999) A Theory of Justice, Oxford: Oxford University Press.

Ruben, L.J. and Elliot, S.A. (1973) 'Sex discrimination and sex-based mortality tables', Boston University Law Review 53: 624-656.

Ryan, S.R. (1986) 'The elimination of gender discrimination in insurance pricing: does automobile insurance rate without sex?', Notre Dame Law Review 61: 748-776.

Schiek, D. (2000) Differenzierte Gerechtigkeit: Diskriminierungsschutz und Vertragsrecht, Baden-Baden, Nomos Verlagsgesellschaft, p. 498.

Schwarze, R. and Wein, T. (2005) 'Is the market classification of risk always efficient? Evidence from German third party motor insurance', http://www.lse.ac.uk/collections/CARR/pdf/Disspaper32.pdf, February, 1-23.

Suetens, L.P. (1990) 'De rechtspraak van het arbitragehof', in A. Alen and P. Lemmens (eds) Gelijkheid en non-discriminatie, Antwerp: Kluwer Rechtswetenschappen Belgium, pp. 95-115.

Thiery, Y. (2003) 'De antidiscriminatiewet: verzekeren over dezelfde kam?' Revue du Droit Commercial belge 8(March): 646-660.

Tobler, C. (2005) Indirect Discrimination, a Case Study into the Development of the Legal Concept of Indirect Discrimination under EC Law, Antwerp, Oxford: Intersentia.

Van Drooghenbroeck, J.-F. and Van Drooghenbroeck, S. (2004) 'Egalité et droit des assurances automobiles: De nouvelles données', in B. Dubuisson and P. Jadoul (eds) Du neuf en assurance automobile, Brussels: Academia-Bruylant, pp. 1-59.

Van Schoubroeck, C. and Thiery, Y. (2003) 'Proposal for a Directive on sex discrimination: civil rights "individualistic" tradition vs. insurance "group" tradition', Euredia 4: 585-612.

Van Schoubroeck, C. and Thiery, Y. (2005) 'Discriminatie in verzekering', in H. Cousy and H. Vandenberghe (eds) Aansprakelijkheids - en Verzekeringsrecht, Brugge: Themis - Die Keure, pp. 27-46.

Velaers, J. (2003) 'De horizontale werking van het discriminatieverbod in de antidiscriminatiewet, enkele constitutionele beschouwingen', in X (ed) Vrijheid en Gelijkheid. De horizontale werking van het gelijkheidsbeginsel en de nieuwe antidiscriminatiewet, Antwerp: Maklu, pp. 287-326. 
Vrielink, J. (2003a) 'De Belgische anti-discriminatiewet. Een kritische bespreking', in UFSIA (ed) Vrijheid en Gelijkheid. De horizontale werking van het gelijkheidsbeginsel en de nieuwe antidiscriminatiewet, Antwerp: Maklu, pp. 189-244.

Vrielink, J. (2003b) 'Gelijke behandeling in Nederland, een bespreking van de Nederlandse Algemene Wet Gelijke Behandeling', in UFSIA (ed) Vrijheid en Gelijkheid. De horizontale werking van het gelijkheidsbeginsel en de nieuwe antidiscriminatiewet, Antwerp: Maklu, pp. 757-784.

Waddinton, L. and Bell, M. (2001) 'More equal than others: distinguishing European Union Equality directives', Common Market Law Review 38: 587-611.

Wagner, G.G. (2003) 'Aktueller Kommentar', Economic Bulletin (October): afl. 10.

Wils, W. (1994) 'Insurance risk classifications in the EC: regulatory outlook', Oxford Journal of Legal Studies 3: 449-467.

Wortham, L. (1986a) 'Insurance classification: too important to be left to the actuaries', Michigan Journal of Law Reform 19: 349-423.

Wortham, L. (1986b) 'The economics of insurance classification: The sound of one invisible hand clapping', Ohio State Law Journal 47: 835-890.

\section{About the Authors}

Yves Thiery is a research fellow of the Belgian Fund for Scientific Research - Flanders and assistant at the Faculty of law at the K.U. Leuven University, Belgium.

Caroline Van Schoubroeck is a professor at the K.U. Leuven University, Belgium and teaches insurance law. 